\title{
Optimasi Peletakan Pola Busana pada Kain Menggunakan Algoritma Genetika
}

\author{
Davin Masasih, Nanik Suciati, dan Chastine Fatichah \\ Departemen Informatika, Institut Teknologi Sepuluh Nopember (ITS) \\ e-mail: nanik@if.its.ac.id
}

\begin{abstract}
Abstrak-Produksi pakaian dalam jumlah banyak tentu akan menghabiskan banyak waktu dan tenaga. Seorang pembuat pola harus menggandakan pola satu per satu dan harus memikirkan pemetaan pola pada kain yang tepat. Pemetaan yang seadanya akan berdampak pada biaya industri dikarenakan bahan baku mengambil peranan yang sangat penting di dalam efisiensi produksi. Dengan kuantitas bahan baku kain yang minimal, diusahakan dapat menghasilkan kuantitas pola yang maksimal. Oleh karena itu, optimasi bahan baku perlu dilakukan guna mendapatkan tingkat efisiensi produksi yang tinggi, yaitu kebutuhan bahan seminimum mungkin. Pada penelitian ini diimplementasikan algoritma genetika untuk menyelesaikan permasalahan optimasi peletakan pola busana pada kain. Algoritma genetika mampu menyelesaikan masalah kombinatorial dengan waktu yang singkat sehingga memberikan solusi terbaik. Sistem menggunakan metode 2-point crossover pada proses pindah silang, pertukaran gen pada proses mutasi, seleksi dengan Stochastic Universal Sampling, dan evaluasi dengan pergeseran per piksel untuk menghitung nilai fitness yaitu lebar kain minimum yang diperlukan. Data yang digunakan pada sistem berjumlah 339 pola yang terdiri dari berbagai macam pola busana mulai dari atasan, rok, celana, macam-macam model lengan dan kerah, serta gaun. Pola-pola tersebut divisualisasikan dalam format Scalable Vector Graphics. Uji coba dilakukan pada kain berukuran 500x150 dengan variasi banyak generasi yakni 3, 5, 7, 9, dan 11 serta variasi mutation rate dan crossover rate mulai dari 0.1 sampai 0.9. Pada uji coba dengan 6 pola diperoleh hasil terbaik pada generasi 7 , mutation rate 0.3 , dan crossover rate 0.6 dengan kebutuhan kain minimum yakni 137 piksel atau setara dengan $137 \mathrm{~cm}$.
\end{abstract}

Kata Kunci-Algoritma Genetika, Optimasi, Peletakan Pola Busana, Scalable Vector Graphics.

\section{PENDAHULUAN}

$\mathbf{I}_{\mathrm{p}}^{\mathrm{N}}$ NDUSTRI konveksi atau garment mengalami perkembangan pesat saat ini. Industri di bidang tekstil dapat berkembang karena pakaian merupakan salah satu kebutuhan primer manusia. Proses produksi pakaian oleh pribadi atau setingkat konveksi biasanya masih menggunakan metode manual. Mulai dari pembuatan pola, pemotongan kain, penjahitan, washing/dyeing, buang benang, ironing/setrika, labeling hingga packing [1]. Produksi pakaian dalam jumlah banyak tentu akan menghabiskan banyak waktu dan tenaga. Seorang pattern maker harus menggandakan pola satu per satu dan harus memikirkan pemetaan pola pada kain yang tepat. Pemetaan yang seadanya akan berdampak pada biaya industri. Ini dikarenakan bahan baku mengambil peranan yang sangat penting di dalam efisiensi produksi. Dengan kuantitas bahan baku produk yang minimal, diusahakan dapat menghasilkan kuantitas produk yang maksimal. Oleh karena itu optimasi bahan baku perlu dilakukan guna mendapatkan tingkat efisiensi produksi yang tinggi, yaitu kebutuhan bahan seminimum mungkin. Penelitian terkait optimasi bahan baku telah dilakukan sebelumnya dengan menggunakan algoritma A*. Penelitian mengenai peletakan pola pakaian dengan algoritma tersebut memperoleh hasil yang kurang optimal karena masih menyisakan ruang diantara pola yang cukup banyak [2]. Masih dengan masalah yang sama, dalam penelitian lain juga telah dilakukan optimasi pemanfaatan bahan baku pada industri mebel menggunakan algoritma genetika dengan Corner Junction. Penelitian tersebut menghasilkan nilai rata-rata fitness terkecil sebesar 0.6 sedangkan nilai rata-rata terbesar dihasilkan sebesar 0.9 yang menunjukkan kemampuan belajar individu terhadap individu sebelumnya menjadi lebih tinggi sehingga mampu mempertahankan keberagaman populasi [3]. Permasalahan optimalisasi peletakan pola busana juga sudah pernah diimplementasikan pada dotted-board model dengan Extended Local Search [4]. Penelitian lain menggunakan Extended Local Search dan Polygon Grouping untuk bangun 2D tidak beraturan [5].

Pada penelitian ini akan diusulkan algoritma genetik untuk menyelesaikan masalah optimasi pada bahan baku kain agar menghasilkan keuntungan yang maksimum dengan jumlah bahan baku yang minimum. Metode algoritma genetik lebih unggul dibandingkan dengan metode Greedy dan Brute Force. Dalam kasus optimasi metode Brute Force memakan waktu komputasi yang lama untuk mencari solusi karena mencoba seluruh kemungkinan yang ada dari awal hingga akhir. Sedangkan pada algoritma Greedy, jika data yang digunakan sangat kompleks, algoritma tersebut tidak mampu memberikan hasil yang optimum meskipun waktu komputasinya relatif cepat. Alasan utama mengapa algoritma genetika digunakan pada penelitian ini karena algoritma tersebut memiliki karakteristik yang sama dengan permasalahan optimasi bahan baku dalam kehidupan nyata. Adapun karakteristik tersebut yaitu algoritma genetika mampu menyelesaikan permasalahan kombinatorial dengan waktu yang singkat. Selain itu algoritma genetika juga mampu menyelelesaikan masalah optimasi dengan memberikan solusi terbaik bahkan pada model matematika yang rumit [6]. 


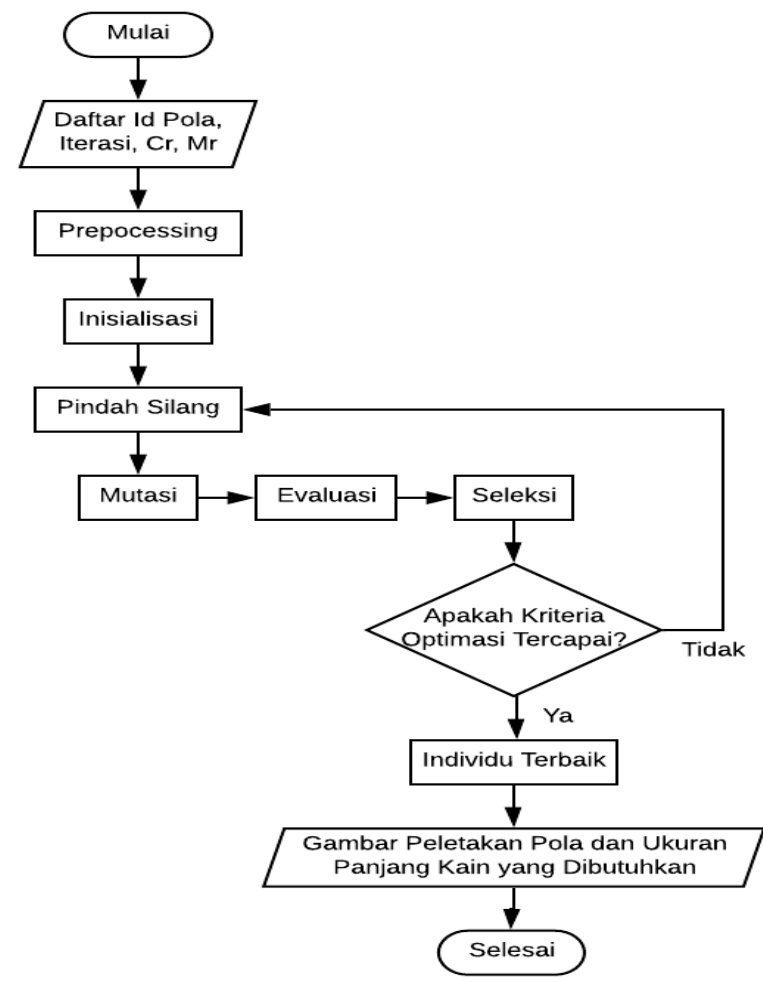

Gambar 1. Diagram Alir Sistem yang Dibangun

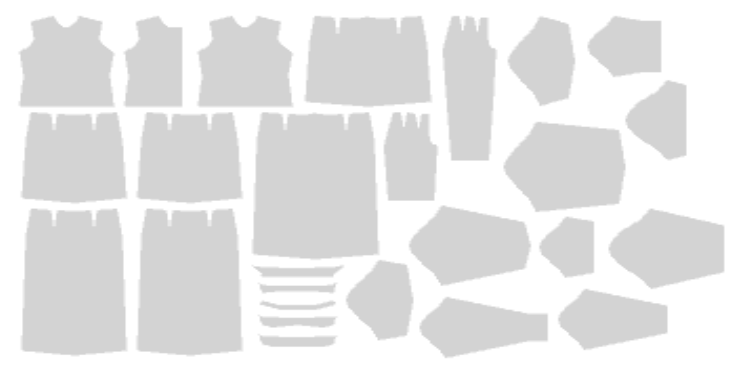

Gambar 2. Contoh Pola Busana

\section{II.TINJAUAN PUSTAKA}

\section{A. Algoritma Genetika}

Algoritma genetika merupakan metode optimasi probabilistik yang didasarkan pada prinsip-prinsip genetika dan evolusi [7]. Evolusi sendiri diartikan sebagai suatu proses yang didasarkan pada reproduksi seksual dan aseksual, seleksi alam, mutasi, dan sebagainya. Selama beberapa generasi, organisme biologis berevolusi secara acak untuk dapat bertahan hidup mengikuti perubahan alam. Sedangkan genetika merupakan ilmu yang berkaitan dengan mekanisme yang bertanggung jawab atas persamaan dan perbedaan dalam suatu spesies. Genetika digunakan untuk membedakan antara keturunan dan variasi. Di alam, seorang individu akan bersaing satu sama lain untuk mendapatkan sumber daya serta pasangan untuk reproduksi. Karena seleksi ini, individu yang paling dapat beradaptasi akan menghasilkan keturunan yang relatif besar. Selama reproduksi, penggabungan karakteristik yang baik dari induk dapat menghasilkan keturunan terbaik yang memiliki kebugaran yang lebih besar daripada induknya [8].
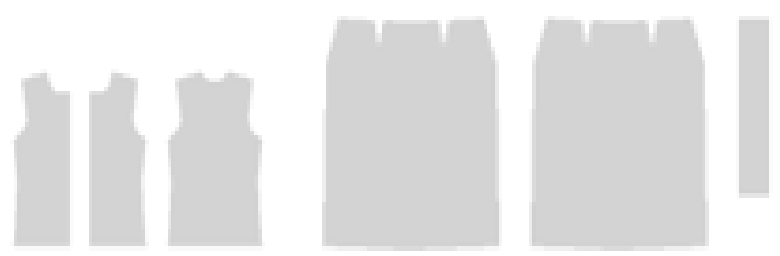

Gambar 3. Pola I

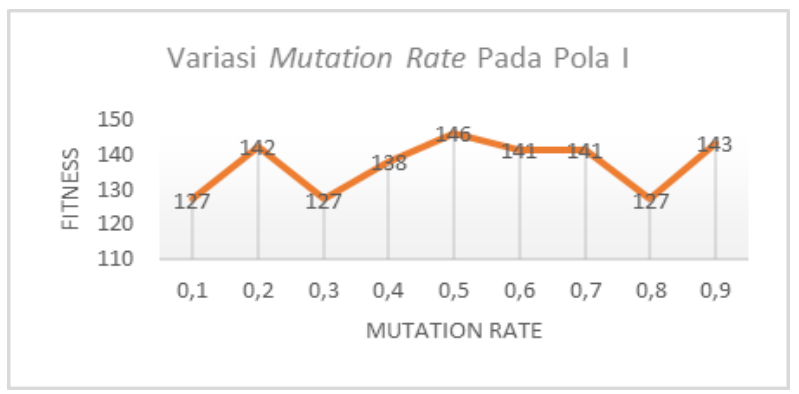

Gambar 4. Hasil Uji Coba Variasi Mr pada Pola I

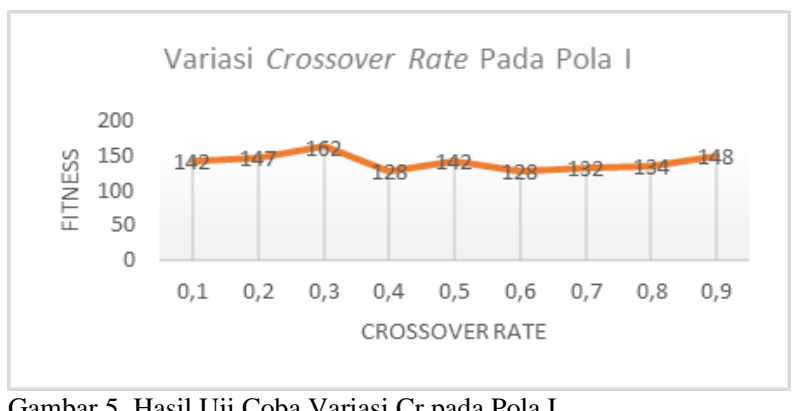

Gambar 5. Hasil Uji Coba Variasi Cr pada Pola I

\section{B. Siklus Algoritma Genetika}

Pengembangan solusi untuk masalah pencarian pada algoritma genetika adalah sebagai berikut [7]: (1)Inisialisasi. Pada awal penerapan algoritma genetika dibutuhkan pembentukan populasi awal dari kandidat solusi. Jumlah individu dalam satu populasi, jumlah kromosom dari tiap individu, representasi kromosom, representasi gen, jumlah iterasi atau generasi maksimal, dan perhitungan nilai fitness harus ditentukan pada tahap ini. Populasi awal dihasilkan melalui proses pemilihan secara acak dari kandidat solusi; (2)Evaluasi. Nilai-nilai kebugaran atau fitness dari kandidat solusi dievaluasi. Nilai fitness adalah nilai yang menyatakan baik atau tidaknya suatu solusi (individu). Nilai ini dijadikan acuan dalam mencapai nilai optimal dalam algoritma genetika. Perhitungan nilai fitness berbeda-beda bergantung kebutuhan pada masalah yang terkait; (3)Seleksi. Seleksi mengalokasikan lebih banyak salinan dari solusi tersebut dengan nilai fitness yang lebih tinggi untuk menemukan solusi terbaik. Pada tahap ini dilakukan pemilihan orang tua untuk kemudian meregenerasi anak untuk menciptakan populasi baru. Terdapat 6 metode seleksi yang dapat diterapkan untuk memilih individu orang tua [9]; (4)Pindah Silang. Rekombinasi menggabungkan bagian dari dua atau lebih solusi induk untuk menciptakan solusi baru yang mungkin lebih baik (yaitu keturunan). Kromosom yang ada pada induk dibagi secara acak dan digabung, dengan konsekuensi beberapa gen berasal dari satu orang tua 


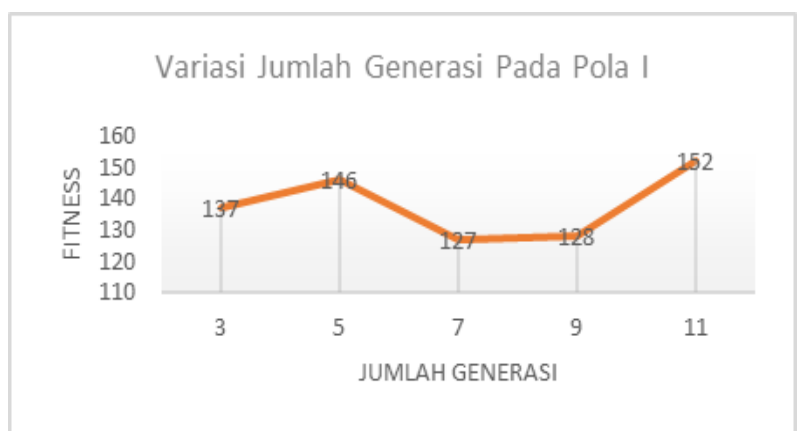

Gambar 6. Hasil Uji Coba Variasi Generasi pada Pola I

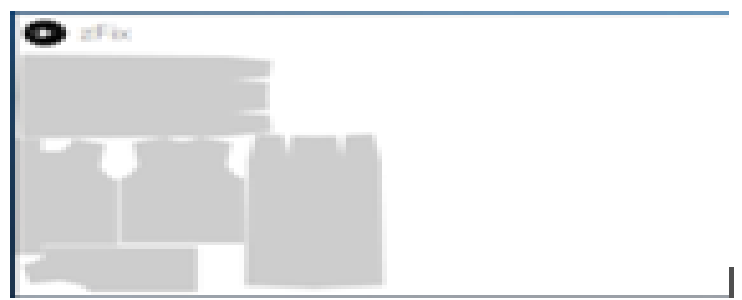

Gambar 7. Hasil Uji Coba Variasi Terbaik pada Pola I

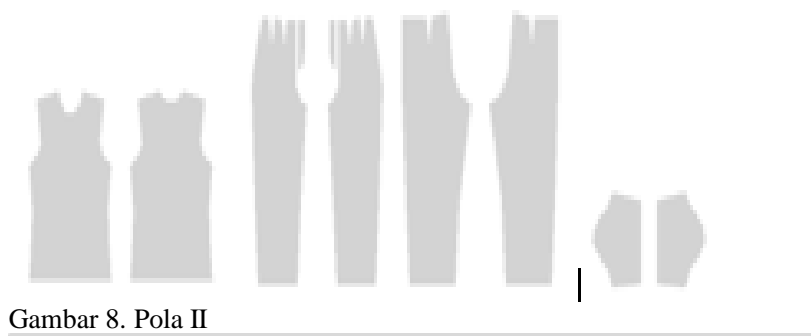

Gambar 8. Pola II

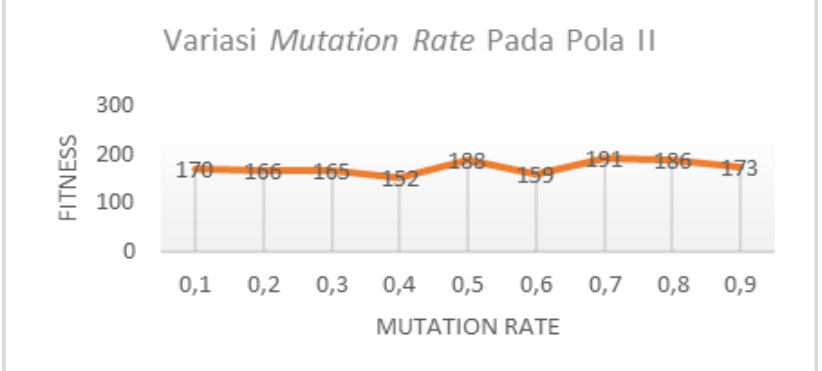

Gambar 9. Hasil Uji Coba Variasi Mr pada Pola II

sementara yang lain berasal dari orang tua lainnya. Pindah silang atau crossover merupakan metode mengurangi materi genetika baru dan mempertahankan keanekaragaman genetika yang dihasilkan dari orang tua dengan kinerja yang baik; (5)Mutasi. Sementara rekombinasi beroperasi pada dua atau lebih kromosom orangtua, mutasi secara lokal dan acak memodifikasi solusi. Ada banyak variasi mutasi, tetapi biasanya melibatkan satu atau lebih perubahan yang dilakukan pada sifat individu. Dengan kata lain, mutasi melakukan secara acak di sekitar kandidat solusi; (6)Replacement. Populasi keturunan yang dibuat oleh seleksi, rekombinasi, dan mutasi akan menggantikan populasi orang tua asli. Populasi yang baru ini terdiri dari campuran kromosom ataupun gen dari orang tua. Populasi terpilih kemudian akan digunakan dalam iterasi berikutnya.

\section{Scalable Vector Graphics (SVG)}

SVG adalah platform untuk menggambarkan aplikasi grafis 2D dalam bahasa XML [10]. Platform SVG menawarkan grafik XML untuk web melalui tiga jenis objek

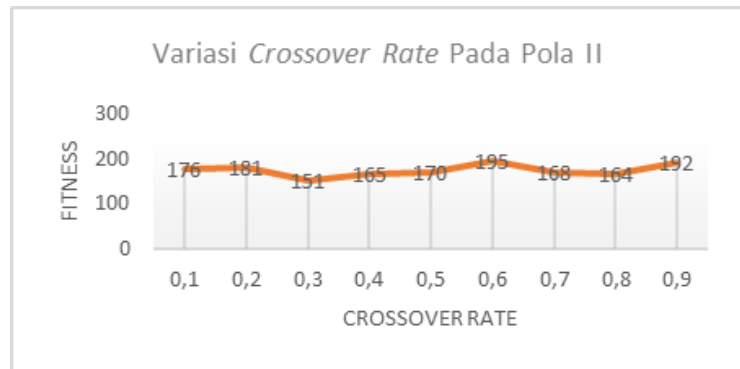

Gambar 10. Hasil Uji Coba Variasi Cr pada Pola II

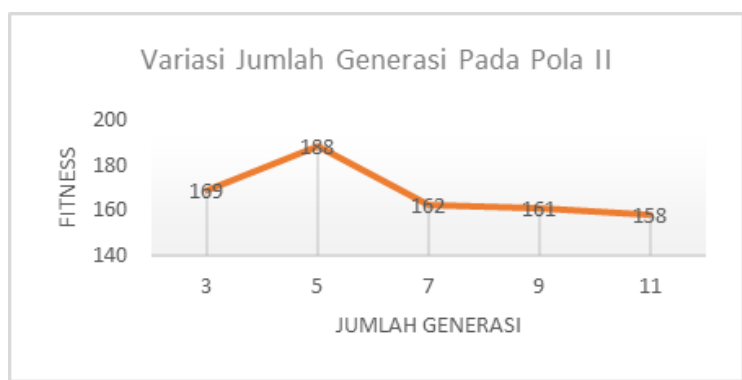

Gambar 11. Hasil Uji Coba Variasi Generasi pada Pola II

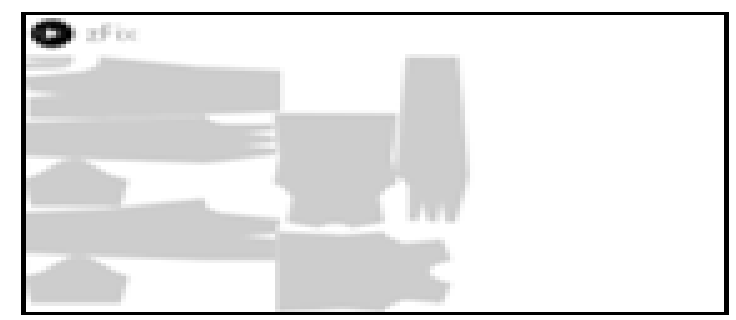

Gambar 12. Hasil Uji Coba Variasi Terbaik pada Pola II
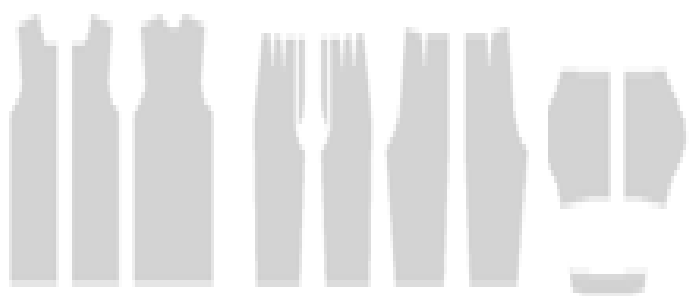

Gambar 13. Hasil Uji Coba Variasi Mr pada Pola III

grafik: bentuk grafik vektor (garis dan kurva), gambar, dan teks. Objek dapat dikelompokkan, ditransformasikan, serta diwakili secara dinamis dan interaktif. Kelebihan dari format SVG adalah ukurannya yang kecil. Selain itu format ini mudah untuk dikompres dibandingkan dengan format lainnya. Grafis SVG dapat dicetak dalam resolusi yang tinggi karena gambar dengan format SVG merupakan gambar vektor, sehingga dapat diperbesar tanpa kehilangan kualitas sama sekali.

\section{D.Processing}

Processing merupakan sebuah perangkat lunak yang berfungsi dalam pembuatan gambar, animasi, dan interaksi. Processing memiliki 2 fungsi utama yaitu fungsi $\operatorname{setup()~dan~}$ fungsi $\operatorname{draw}()$ [11]. Fungsi setup() dipanggil hanya sekali, yaitu ketika pertama kali program dijalankan. Sedangkan fungsi $\operatorname{draw}()$ dipanggil setelah menjalankan fungsi setup(), kemudian fungsi ini diulang secara terus-menerus selama sistem berjalan. Fungsi ini memungkinkan sistem untuk merespon interaksi pengguna secara cepat dan realtime. 


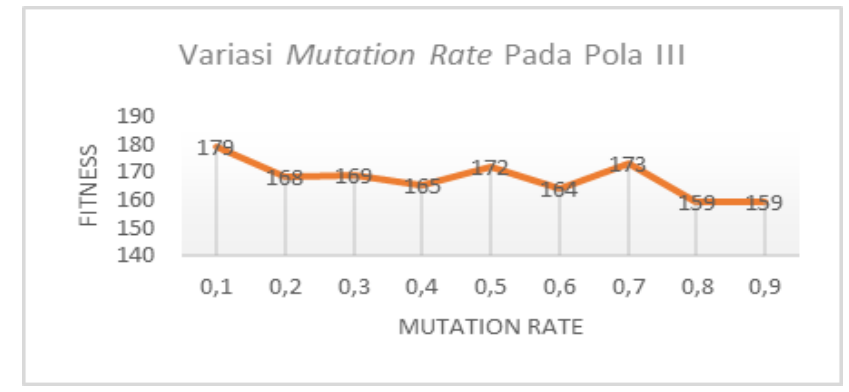

Gambar 14. Hasil Uji Coba Variasi Mr pada Pola III

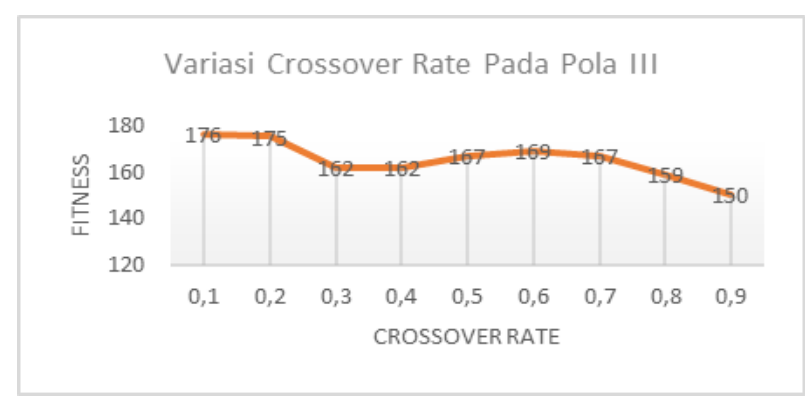

Gambar 15. Hasil Uji Coba Variasi Cr pada Pola III

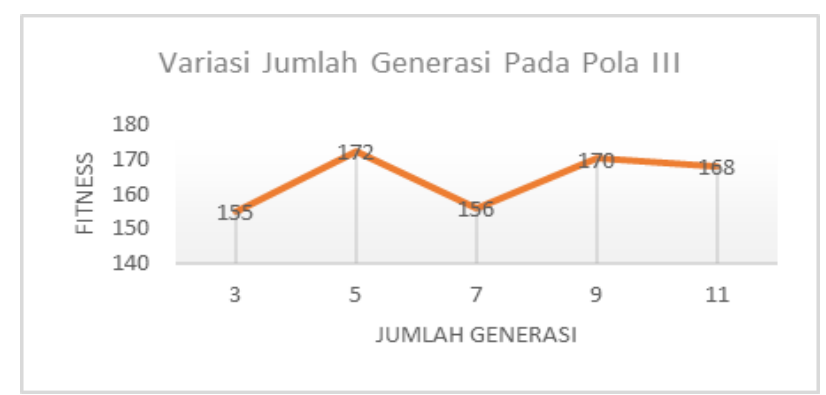

Gambar 16. Hasil Uji Coba Variasi Generasi pada Pola III

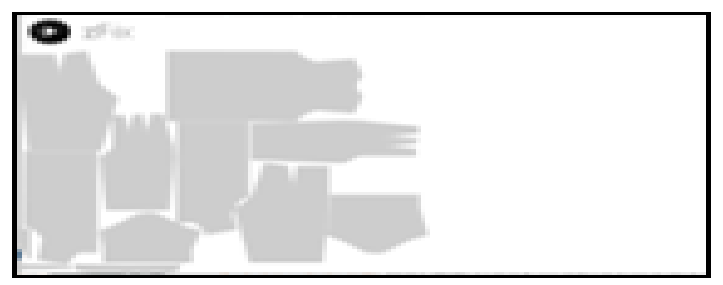

Gambar 17. Hasil Uji Coba Variasi Terbaik pada Pola III

\section{ANALISIS DAN PERANCANGAN}

\section{A. Peranvangan Data}

Data yang digunakan dalam sistem ini dibuat berdasarkan pada Buku Penuntun Membuat Pola Busana Tingkat Dasar karya Soekarno [12]. Pola-pola tersebut divisualisasikan dalam format Scalable Vector Graphics (SVG). Data terdiri dari berbagai macam pola mulai dari baju atasan wanita, baju atasan pria, rok, celana, macam-macam model lengan dan kerah baju, serta gaun.

\section{B. Desain Umum Sistem}

Pada tugas akhir ini akan dibuat aplikasi berbasis Processing yang bertujuan untuk mengoptimalkan peletakan pola pada kain. Metode yang digunakan adalah algoritma genetika sebagai alternatif yang diharapkan memiliki hasil yang maksimal. Aplikasi ini menerima input berupa id pola, jumlah iterasi atau generasi, crossover rate $(\mathrm{Cr})$ atau peluang pindah silang, mutation rate $(\mathrm{Mr})$ atau peluang mutasi, dan output berupa gambaran peletakan pola. Diagram alir pada sistem aplikasi yang akan dibangun ditunjukkan pada Gambar 1 terdiri dari

\section{1) Preprocessing}

Preprocessing terhadap data dilakukan melalui perubahan posisi verteks acuan pola dengan nilai acuan $(0,0)$. Perubahan ini dilakukan karena posisi dari pola dalam format SVG yang acak. Setiap verteks pada pola akan diubah sebagaimana hingga pusat rotasi pola akan terletak tepat di koordinat tengah dari pola tersebut. Dalam tahap preprocessing ini, setiap pola akan diinisialisasi menjadi kromosom. Berikut adalah representasi tiap kromosom: Z, X, Y, R. Keterangan: Z adalah id pola yang tersimpan pada file SVG; $X$ adalah koordinat $\mathrm{X}$ atau absis dari posisi acuan pola; Y adalah koordinat $\mathrm{y}$ atau ordinat dari posisi acuan pola; $\mathrm{R}$ adalah sudut putar pola. Contoh dari kromosom seperti ditunjukkan di bawah ini:

$$
\text { [ “A011”, 23, 54, 270 ] }
$$

Diartikan sebagai pola dengan id A011 berada pada absis 23 dan ordinat 54 dengan sudut putar 270 derajat. Representasi gen untuk X, Y, dan A menggunakan real value atau nilai asli. Sedangkan representasi untuk gen $\mathrm{Z}$ menggunakan 4 digit kombinasi angka dan huruf dengan ketentuan sebagai berikut: "A011". Keterangan: A mewakili kode jenis pola; 0 mewakili kode gender (wanita atau pria); 1 mewakili kode ukuran pola $(\mathrm{S}=1, \mathrm{M}=2$, atau $\mathrm{L}=3) ; 2$ mewakili kode sub jenis pola.

\section{2) Inisialisasi}

Populasi awal dibentuk secara random di seluruh ruang pencarian. Jumlah populasi disesuaikan dengan inputan yang telah diberikan. Urutan id individu dalam populasi dipastikan tidak ada yang sama dengan individu lainnya. Begitu pun dalam satu individu dipastikan tidak memiliki id yang sama antar kromosomnya. Sudut rotasi untuk masingmasing kromosom tiap individu juga akan ditentukan pada tahap ini. Sudut akan ditetapkan berdasarkan hasil random dari ruang pencarian yakni $0,90,180$, dan 270. Ukuran sudut tersebut dipilih berdasarkan tekstur serat kain yang biasanya akan menjadi fokus seorang penjahit dan industri konveksi atau garment. Pemotongan yang salah bisa membuat serat kain. rusak sehingga rotasi sudut dalam peletakan pola pada kain tidak dapat diabaikan.

3) Evaluasi

Pada awalnya, setiap kromosom akan diletakkan tepat di posisi kiri atas dari kain. Kemudian dicek kemungkinan overlap .dengan pola sebelumnya dengan cara mengecek tiap piksel warna pada kain. Apabila hal tersebut terjadi, posisi pola akan digeser dengan aturan mendahulukan menggeser secara vertikal ke bawah. Kemudian akan dilakukan pengecekan terhadap cukup atau tidaknya pola berada di posisi bawah kain dengan mencari posisi $y$ maksimal. Jika posisi $y$ maksimal mencapai tinggi kain maksimum dan masih terdeteksi adanya overlap, maka tinggi kain dianggap tidak cukup sehingga pola harus digeser ke kanan. Posisi $x$ dengan nilai maksimal akan digunakan sebagai nilai fitness atau nilai kebugaran. Nilai fitness dalam permasalahan ini adalah kebutuhan kain seminimal mungkin. Evaluasi nilai fitness dihitung berdasarkan lebar minimum 
kain yang dibutuhkan. Semakin panjang lebar yang dibutuhkan pada kain maka nilai fitness nya semakin buruk. 4) Pindah Silang

Pada tahap ini jumlah kemungkinan penukaran kromosom didasarkan pada nilai input berupa Crossover Rate $(\mathrm{Cr})$. Hasil dari $\mathrm{Cr}$ dikalikan dengan jumlah populasi menghasilkan jumlah individu baru (offspring) yang mungkin terbentuk. Dari kemungkinan jumlah tersebut akan dipilih 2 individu secara acak yang akan berperan sebagai orang tua. Pertukaran kromosom antar orang tua akan didasarkan pada metode 2-point crossover. 2 poin yang dimaksud adalah nilai random dari ukuran panjang kromosom individu. Range atau wilayah dari 2 titik menentukan kromosom mana saja yang mengalami pertukaran. Dari pertukaran tersebut, memungkinkan terjadinya duplikasi id kromosom dalam satu individu. Oleh karena itu, setelah kromosom di dalam range tertukar semua, akan dilakukan pengecekan duplikasi. Apabila terdapat dua id yang sama dalam satu kromosom, maka kromosom diluar range yang sama akan ditukar dengan kemungkinan kromosom yang menghilang

\section{5) Mutasi}

Pada tahap mutasi, jumlah kemungkinan penukaran kromosom juga didasarkan pada parameter input yakni Mutation Rate $(\mathrm{Mr})$. Hasil dari $\mathrm{Mr}$ dikalikan dengan jumlah populasi menghasilkan jumlah individu baru (offspring) yang mungkin terbentuk. Dari kemungkinan jumlah tersebut akan dipilih masing-masing 1 individu secara acak. Mutasi dilakukan dengan menukarkan sudut rotasi antar 2 kromosom berbeda dalam satu individu. Penentuan kromosom terpilih juga didasarkan pada angka random.

6) Seleksi

Pada tahap ini populasi awal dan offspring digabung lalu dirangking berdasarkan fitness terbaik. Semakin baik nilai fitness sebuah individu, maka probabilitas untuk terpilih semakin besar. Individu bertahan dipilih berdasarkan metode Stochastic Universal Sampling (SUS). Metode ini menggunakan sistem Roulette Wheel yang titik pemilihan individu-nya diletakkan pada 2 tempat berbeda sehingga dalam sekali pemilihan akan dihasilkan 2 individu sekaligus atau satu pasang orangtua. Pemilihan dilakukan secara acak untuk memilih individu pertama. Individu kedua diperoleh dari nilai random dikurangi dengan suatu nilai yang telah ditentukan sebelumnya.

\section{7) Menampilkan Hasil}

Individu hasil dari proses pindah silang, mutasi, dan seleksi belum tentu sudah optimal. Dibutuhkan beberapa kali proses untuk dapat menghasilkan individu terbaik yang diharapkan. Individu dengan nilai fitness terbaik atau kebutuhan bahan seminimum mungkin menjadi solusi dari optimasi yang diharapkan. Hasil individu terbaik akan digambarkan pada kain sesuai dengan posisi $x, y$, dan sudut rotasi dari individu tebaik.

\section{PENGUJIAN DAN EVALUASI}

\section{A. Dataset}

Data yang digunakan dalam sistem ini dibuat berdasarkan pada Buku Penuntun Membuat Pola Busana Tingkat Dasar karya Soekarno [12]. Pola-pola tersebut divisualisasikan dalam format Scalable Vector Graphics (SVG). Data terdiri dari berbagai macam pola mulai dari baju atasan, rok, celana, macam-macam model lengan dan kerah baju, serta gaun. Masing-masing pola tersedia dengan ukuran S, M, dan L. Pola dibuat dengan perbandingan $1 \mathrm{~cm}=1$ piksel. Contoh pola busana dapat dilihat pada Gambar 2.

\section{B. Evaluasi Pengujian}

Hasil pengujian menilai keefektifan tiap parameter uji coba pada optimasi peletakan pola busana pada kain menggunakan algoritma genetika. Pada uji coba dengan Pola I (Gambar 3) berjumlah 6 yang terdiri dari pola baju bukaan depan wanita dan rok standar panjang menunjukkan bahwa tingkat peluang mutasi cukup rendah. Fitness terbaik pada saat $M r$ bernilai 0.1 dan $0.3, C r$ bernilai 0.4 dan 0.6 , dan jumlah generasi 7. Hal ini ditunjukkan masing-masing pada Gambar 4, Gambar 5, dan Gambar 6. Penggabungan dari variasi jumlah generasi, $\mathrm{Mr}$, dan $\mathrm{Cr}$ terbaik untuk Pola I menunjukkan bahwa individu optimal diperoleh pada saat $M r=0.3, C r=0.6$, dan jumlah generasi 7 dengan nilai fitness 137 dapat dilihat pada Gambar 7. Nilai fitness tersebut merupakan nilai terbaik dari seluruh hasil uji coba pada variasi $\mathrm{Mr}, \mathrm{Cr}$, maupun jumlah generasi terhadap Pola I. Pada uji coba Pola II (Gambar 8) berjumlah 10 yang terdiri dari pola baju tanpa bukaan wanita, celana panjang, dan lengan licin pendek menunjukkan bahwa fitness terbaik pada saat $\mathrm{Mr}=0.4, \mathrm{Cr}=0.3$, dan jumlah generasi 1 . Hal ini ditunjukkan masing-masing pada Gambar 9, Gambar 10, dan Gambar 11. Penggabungan dari variasi jumlah generasi, $M r$, dan $C r$ terbaik untuk Pola II menunjukkan bahwa individu optimal memiliki nilai fitness 169 dapat dilihat pada Gambar 12. Hasil ini tidak cukup baik karena hasil dari beberapa uji coba variasi $\mathrm{Mr}$ dan $\mathrm{Cr}$ ada yang memiliki nilai fitness lebih baik, yakni mencapai 151. Uji coba berikutnya menggunakan Pola III (Gambar 13) berjumlah 12 yaitu baju atasan pria tanpa bukaan, celana pendek, lengan gladde, dan kerah sport. Variasi $\mathrm{Mr}$ terbaik untuk pola ini bernilai 0.8 dan $0.9, C r$ bernilai 0.9 , sedangkan jumlah generasi 3. Hal ini ditunjukkan masing-masing pada Gambar 14, Gambar 15, dan Gambar 16. Penggabungan dari variasi jumlah generasi, $\mathrm{Mr}$, dan $\mathrm{Cr}$ terbaik untuk Pola III menunjukkan bahwa individu optimal diperoleh pada saat $\mathrm{Mr}=0.8$ dan $\mathrm{Cr}$ = 0.9 dengan nilai fitness 157 dapat dilihat pada Gambar 17 . Hasil ini tidak cukup baik karena hasil dari beberapa uji coba variasi $\mathrm{Mr}$ dan $\mathrm{Cr}$ ada yang memiliki nilai fitness lebih baik, yakni mencapai 150 .

\section{KESIMPULAN DAN SARAN}

\section{A. Kesimpulan}

Berikut adalah kesimpulan dari proses pengerjaan penelitian mulai dari tahap analisis, desain, implementasi, hingga pengujian antara lain; (1)Masalah optimasi peletakan pola dapat dimodelkan menggunakan algoritma genetika melalui proses pindah silang dengan 2-point crossover, mutasi dengan pertukaran sudut rotasi, dan seleksi dengan Stochastic Universal Sampling (SUS); (2)Representasi kromosom dengan 4 gen, yakni $Z$ sebagai id dengan representasi gen 4 digit, $X$ sebagai posisi $x$ dari pola dengan nilai real atau asli, $Y$ sebagai posisi $y$ dari pola dengan nilai 
real atau asli, dan A sebagai sudut rotasi pola dengan nilai asli; (3)Pembentukan populasi awal dilakukan dengan pencarian secara random sebanyak 4 individu tiap populasi dengan memperhatikan batasan duplikasi; (4)Kinerja algoritma genetika diukur berdasarkan kebutuhan bahan kain paling minimum berdasarkan posisi $x$ ujung kanan dari bahan melalui pengecekan warna pada tiap piksel; (5)Hasil terbaik dari beberapa variasi banyak pola didasarkan pada parameter yang berbeda-beda dengan kecenderungan semakin banyak pola maka mutation rate semakin besar; (6)Hasil uji coba terbaik pada uji coba 4 dengan banyak pola 6 buah dihasilkan pada jumlah generasi 7 , mutation rate 0.3 , dan crossover rate 0.6 , dengan nilai fitness atau kebutuhan kain minimum $137 \mathrm{~cm}$; (7)Waktu yang dibutuhkan untuk satu kali iterasi proses masih lama dikarenakan pola busana yang bukan merupakan bangun beraturan sehingga harus menggunakan pergeseran per piksel untuk menemukan area optimal yang dapat ditempati pola.

\section{B. Saran}

Berikut merupakan beberapa saran untuk perbaikan dan pengembangan sistem di masa akan dating antara lain: (1)Perlu dilakukan uji coba lebih lanjut pada optimasi peletakan pola busana menggunakan algoritma genetic dengan metode pindah silang, mutasi, dan seleksi lain untuk dapat ditemukan hasil yang lebih optimal; (2)Mencari cara agar peletakan pola busana tidak memakan waktu yang lama dikarenakan pergeseran yang dilakukan per piksel.

\section{DAFTAR PUSTAKA}

[1] "Bagaimana Alur Produksi Pakaian di Industri." https://pabrikkaosbandung.com/bagaimana-alur-produksi-pakaian-diindustri/.

[2] S. D. D. A. P. Irma Amalia Dewi, Asep Nana H., "Algoritma A* Dalam Peletakan Pola Pakaian Pada Kain,” pp. 3-5, 2017.

[3] andika indra Kusuma, A. W. Widodo, and M. A. Fauzi, "Optimasi Sisa Bahan Baku pada Industri Mebel Menggunakan Algoritma Genetika," J. Pengemb. Teknol. Inf. dan Ilmu Komput. Univ. Brawijaya, vol. vol 2, No, no. 3, pp. 1119-1125, 2018, [Online]. Available: http://j-ptiik.ub.ac.id.

[4] F. Bimantoro, N. Suciati, and I. Arieshanti, "Dotted-Board Model dan Extended Local Search untuk Optimalisasi Tata Letak Pola Busana pada Bahan Bermotif dengan Mempertimbangkan Aturan Keserasian Motif," pp. 75-85.

[5] F. T. Anggraeny, N. Suciati, and A. Yuniarti, "Extended Local Search and Polygon Grouping for 2D Irregular Strip Packing Problem," in Proceedings - International Conference on ICT for Smart Society 2013: “Think Ecosystem Act Convergence", ICISS 2013, 2013, pp. 10-15, doi: 10.1109/ICTSS.2013.6588054.

[6] Wayan Firdaus Mahmudy, "Algoritma Evolusi," Progr. Teknol. Inf. Dan Ilmu Komputer, Univ. Brawijaya, Malang, 2013.

[7] G. K. Kumala Sastry, David Goldberg, "Genetic Algorithms."

[8] W. F. Mahmudy, "Dasar-Dasar Algoritma Evolusi," Univ. Brawijaya, 2015 .

[9] S. N. S. S.N. Deepa, Introduction to Genetic Algorithms. New York: Springer-Verlag, 2008.

[10] M. Vlada, "SVG Language ( Scalable Vector Graphics ) For 2D Graphics in XML and Applications," no. January 2008, pp. 297-306, 2008.

[11] “Processing.org." https://processing.org/ (accessed May 10, 2020).

[12] Soekarno, Penuntun Membuat Pola Busana Tingkat Dasar, Jakarta: PT Gramedia Pustaka Utama, 2012. 